\title{
What prospects for perestroika?
}

\section{The Soviet scientific community seems to have won a substantial measure of freedom in the past year, but the underlying problems of the Soviet economy cast a cloud over change.}

\section{Moscow}

NoT even the unseasonably warm weather (on at least two days last week, the snow was melting) can explain people's cheerfulness - indeed, most would prefer that the weather would be what it should be at this time of the year, crisp and cold. Much of the explanation is that things have indeed changed a great deal, and for the better. Most noticeably, people who a year ago had never been abroad now seem to be regular travellers to what is still called the West (but which includes Japan). For those not travelling, it is now possible to find periodicals such as the International Herald Tribune in the hotels, but shockingly out of date.

There have been notable changes in the regulations affecting scientific work, and in the conscientiousness with which they are carried through, that have simplified once-complicated tasks. On travel, for example, an institute director's decision is usually, now, sufficient.

Similarly, with the publication of research reports, the formal approval of manuscripts by the parent academy (always a formality, but a thief of time) has been abandoned. An institute's director can approve publication in a Soviet journal, but the state copyright board which formally exploits overseas the intellectual property of Soviet citizens must still approve of publication in foreign journals. The decision of at least one writer to defy the board's authority (on the grounds that he would earn more without its intervention) has even raised the question of how long that system can continue to apply to scientific articles (where, usually, no money changes hands).

This betokens a kind of permissiveness that is unfamiliar. While the limits of glasnost remain to be explored fully (by experiment) and defined (presumably by reproof of some kind), even those in authority who make no secret of their uneasiness at present trends are evidently diffident at making too much fuss. But $\mathrm{Mr}$ Mikhail Gorbachev's 2-hour speech to a gathering of intellectuals at the Kremlin on 7 January, which argued among other things for support and also for self-restraint, may suggest that definition may not be far away.

Meanwhile, people have more elections to occupy their attention. In at least some of the Soviet Academy's institutes, this will be the third occasion in a year in which researchers have been voting on each other's suitability for one or another function. Less than a year ago, institutes were nominating members of the special Party Conference, in October many were electing new directors, now they are nominating people to be deputies in the new constitution's scheme for a representative parliamentary system.

The idea is that the Soviet Union as a whole should elect some 5,000 people to a chamber of deputies that will, this summer, elect from its own number a body known as the Supreme Soviet (at present nominated and largely honorific) to consist of full-time scrutineers of government legislation. The Academy of Sciences has 25 seats in the electoral college (the Soviet Union's philatelists' society also has a quota), the Communist Party as such has 100, but other Party members will no doubt be elected as district representatives.

Academicians Andrei Sakharov and Roald Z. Sagdeev, in that order, seem to be well ahead among the nominations of individual institutes. It is generally believed that, if elected, each would be prepared to stand for the Supreme Soviet. The academy's candidates will be chosen at a meeting this week. There is some ribaldry that one institute, having nominated its own director, decided not to nominate Sakharov as well for fear of undermining its own candidate's chances.

Meanwhile, it is certain that science will be represented at a senior level in the electoral college. Academician G.I. Marchuk, president of the academy, Academicians V. Kotelnikov and Ye. Velikhov (both vice-presidents, the latter now also director of the Kurchatov Institute) together with two other members of the academy appear on the Communist Party's final slate of 100 .

Sakharov himself seems gracefully to have made the transition from exile to statesman foreshadowed by his election to the praesidium (governing council) of the academy three months ago. Back from a first visit to the United States only in December, he has been, at the request of Mr Gorbachev, on a fact-finding visit to Nagorno-Karabakh (the Armenian enclave in Azerbaijan) and has caught the attention of the academy with a powerful speech on ecology. If there were still a vacancy as honorific head of state $(\mathrm{Mr}$ Gorbachev is now both president and Party general-secretary), Sakharov would surely be appointed instantly.

Not all elections have brought such comfort. There is, for example, the sad case of Academician G. N. Basov, awarded a Nobel Prize in 1964 for the development of lasers (jointly with Charles W. Townes of the United States and his own Moscow colleague A.M.Prochorov) and for many years head of the Lebedev Institute in Moscow.

Basov's star began to set when he was not elected as the institute's nominee to the Party conference. Now he has been succeeded at a reorganized institute (strictly, a federation of research groups) by Academician Leonid Keldysch (son of a previous academy president). The final humiliation is that Basov has not been nominated as a deputy by the national "science-awareness" organization (analogous to the British Association for the Advancement of Science) of which he is the president. Yet he is a vigorous and even kindly man, but lacks adroitness.

Is it possible that, unused to free elections, the Soviet Union equates success in particular elections as a proof of all-round competence (and vice versa)? For that matter, it remains to be demonstrated that the election of institute directors by the staff whom they will manage will always produce satisfactory results.

Elections apart, people are worrying about perestroika, the process meant to put the Soviet Union back on its feet. Some welcome the fact that perestroika has further emptied the shops of goods on the paradoxical grounds that complacency is the real enemy, but the lack of a clear economic strategy is daunting.

The abrupt change two weeks ago of the rules affecting cooperatives (a kind of euphemism for private businesses) is a more particular worry. Cooperatives making medical diagnostics (small-scale biotechnology companies) will in future be regulated by ministries, others (as in publishing) are forbidden. The origins of this change are obscure, but seem to embody general discontent with the high prices charged by the cooperators, and the consequent high profits.

Meanwhile, too many rubles chase too few goods, so much so that offers to exchange rubles for foreign currency have become almost indecently open. The chief danger for perestroika in these circumstances is that of instability. Stopgap foreign credits seem the only quick way out. 